\title{
HELMINTHIASIS IN CHILDREN *
}

W. W. MURPHY, M.D.

CHICAGO

The subject of helminthiasis in children has been revived in the literature in the last few years. The statistics as given in the text-books have been drawn from the clinical work in hospitals and private practice and are naturally inaccurate, as many of the cases show no symptoms and the clinical examinations have not been controlled by careful laboratory examination. In the last few years, however, there have been two investigations reported, based on thoroughly scientific work. The earlier work, that of Stiles and Garrison, reported in 1906, gives a thorough digest of the voluminous literature and was practically the only report on the subject in the United States until Schloss reported his series of 310 cases from the clinics of three hospitals in New York. The latter report was the direct stimulus for the present investigation. The percentage of infections (28.57 per cent.) reported in this paper being so much higher than clinical reports would indicate, gave rise to the question whether the percentage rate was really lower among the cases in the Chicago clinics, or whether the routine examinations in the laboratory had been inadequate. With these questions in mind, the present investigation was started.

The work was carried on in the laboratory of the Michael Reese Hospital and extended over a period of eight months. The cases were taken from patients in the Children's Ward in this hospital. They were taken consecutively as they entered without regard to whether they showed any symptoms referable to infection with parasites.

The purpose of the work as outlined was primarily to determine: First, the frequency of infection with intestinal worms in children between the ages of 2 and 12 years; second, the species of parasites harbored; and third, the relative frequency of infection with the different species of parasites.

The question of the constancy of easinophilia in infections with intestinal worms, the number of cases that show the usual symptoms of helminthiasis and the nature of those symptoms, were considered secondarily only, as the cases were all patients admitted to the wards for some affection other than helminthiasis.

* From the department of Pediatrics and the Laboratories of the Michael Reese Hospital, Chicago. 
The method of examination used for diagnosis was a careful macroscopic and microscopic examination of the feces for the parasites, parts or segments of the parasites, their ova or larvæ, and the results reported are based on such findings. As often as it was possible, the stools were obtained after a purge with calomel and in every case that was doubtful or positive the duplicate examinations were after a thorough calomel purge. An average of two and a half stools was obtained from every case, though in thirty-four of the cases it was impossible to obtain more than one stool, owing to the patient disappearang from our observation, or for similar reasons. The technic of the microscopic examination consisted of an emulsion of a small portion, approximately 10 to 15 grams, of the thoroughly mixed feces in 30 c.c. of distilled water, varying the amount as necessary to make a translucent mixture, and from

Table Showixg Common Sxmptoms in Helminthiasis

\begin{tabular}{|c|c|c|c|c|c|c|c|c|c|c|}
\hline 完 & 总 & $\stackrel{\mathscr{W}}{\mathscr{W}}$ & ఖ & 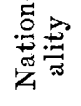 & $\begin{array}{c}\text { Intercur- } \\
\text { rent Disease }\end{array}$ & $\begin{array}{l}\text { Para- } \\
\text { site }\end{array}$ & $\begin{array}{l}\text { Gastroin- } \\
\text { testinal }\end{array}$ & Nervous & $\begin{array}{l}\text { Loss in } \\
\text { Weight }\end{array}$ & Skin \\
\hline 1 & 6 & F. & R. J. & U.S. & Chorea & T.t. & $\begin{array}{l}\text { Apletite } \\
\text { poor }\end{array}$ & $\begin{array}{c}\text { Very } \\
\text { nervous }\end{array}$ & $\ldots \ldots$ & \\
\hline 2 & 10 & M. & R. J. & U. S. & $\begin{array}{l}\text { Mitral and } \\
\text { Aortic Insuf- } \\
\text { ficiency }\end{array}$ & T. t. & $\begin{array}{c}\text { Appetite } \\
\text { poor } \\
\text { abd. distress }\end{array}$ & Restless & $\ldots \ldots$ & $\ldots \ldots$ \\
\hline 3 & 8 & M. & R. J. & U. S. & $\begin{array}{c}\text { Endocar- } \\
\text { ditis }\end{array}$ & T.t. & $\ldots \ldots$ & $\ldots \ldots$ & $\cdots \cdots$ & $\cdots \cdots$ \\
\hline 4 & 4 & M. & R.J. & U.S. & Leg burn & Asc.l & $\cdots$ & $\cdots$ & $\ldots \ldots$ & $\ldots \ldots \ldots$ \\
\hline $\mathbf{5}$ & $21 / 2$ & F. & R.J. & U. S. & $\begin{array}{c}\text { Chronic } \\
\text { Osteo }\end{array}$ & Asc.l & $\ldots \ldots$ & $\ldots \ldots$ & & \\
\hline 6 & 6 & M. & R. J. & U. S. & $\begin{array}{l}\text { Helmin- } \\
\text { thiasis }\end{array}$ & Tae.s & $\begin{array}{l}\text { Appetite } \\
\text { poor }\end{array}$ & Slightly & Slight & $\begin{array}{l}\text { Purpura } \\
\text { hemor- } \\
\text { rhagica }\end{array}$ \\
\hline 7 & 4 & M. & R. J. & U. S. & Burns & Tri.i & $\ldots \ldots$ & Restless & $\ldots \ldots$ & $\ldots \ldots$ \\
\hline
\end{tabular}

this emulsion not less than five preparations were made from each stool by placing a drop on a glass slide and covering with a cover slip. These were then studied very carefully with both the two-thirds and one-sixth objectives. In all, stools from 102 children were examined. The age limit was set at 12 years, as the intention was to confine the investigation entirely to children.

In regard to the nationality, a word must be said, as it may have a direct bearing on the significance and interpretation of the results. The patients were almost entirely of Russian Jewish parentage, although nearly without exception of American birth. The fact that all the statistics of the foreign reports show a very much higher percentage of infections than any of the reports for the United States would make this point vital in interpreting this report as an index to conditions in the United States. 
A very large majority of the cases were taken from the charity wards of the hospital. They represent, therefore, the children from the homes of the poorer classes, where the housing conditions and mode of living are far from good. The questions of occupation, place of residence, rural or city, and previous residence, have all been answered.

Stools were examined, then, from 102 of these patients under 12 years of age and the following results were obtained: Of the 102 children, seven, or 6.86 per cent., harbored parasites, and one case was infected with two species of parasites, making a total of eight infections, or 7.84 per cent. Of these, the Trichiuris trichiura was present four times, or in 3.92 per cent. of the cases; the Ascaris lumbricoides in two, or in 1.96 per cent. of the cases, and one case each of infection with Tania saginata and Trichimonas intestinalis.

Since these seven positive cases were in the hospital with a diagnosis other than helminthiasis, it is difficult to attribute any one symptom or group of symptoms to the one or the other affection. Further, it follows that the symptoms of the intercurrent diseases being most prominent, may overshadow and obscure the manifestations of infection with intestinal parasites and make the interpretation of these evidences difficult and at best presumptive. In the preceding table have been tabulated the symptoms most commonly attributed to helminthiasis.

The blood-picture in the cases shown in the table was as indicated in the following table:

\begin{tabular}{r|r|r|r|r|r|r|r}
\hline Number ........ & 1 & 2 & 3 & 4 & 5 & 6 & 7 \\
\hline $\begin{array}{r}\text { Hemoglobin ...... } \\
\text { Eosinophils } \ldots . . .\end{array}$ & $\begin{array}{r}78 \\
0\end{array}$ & $\begin{array}{r}90 \\
3\end{array}$ & $\begin{array}{r}75 \\
3\end{array}$ & $\begin{array}{r}\text { not } \\
\text { niade }\end{array}$ & $\begin{array}{r}85 \\
5\end{array}$ & $\begin{array}{r}75 \\
8\end{array}$ & $\begin{array}{r}85 \\
0\end{array}$ \\
\hline
\end{tabular}

Taking these up in order, we have first, gastro-intestinal symptoms. Two cases ( 1 and 2) of infection with Trichiuris trichiura and one case (6) with Tonia saginata infection, showed slight gastro-intestinal symptoms. In the two latter cases, no other etiology being determinable, it was fair to suppose that the symptoms were referable to the helminthiasis. In only the one case (6) was this proven by the disappearance of the symptoms following the treatment. Nervous symptoms were seen in three cases $(1,2$ and 7$)$. These three patients showed restlessness and insomnia, but in none of these could these symptoms be determined as due to the parasites, as the intercurrent disease was more probably the cause. No history or record of appreciable loss of weight was given in any one case except that of the boy harboring a fat tapeworm, and here there was only a moderate loss; in no sense an emaciation. There was but one case which showed any skin manifestations (6). This boy showed 
a iather colorless, transparent skin and shortly after the presence of the worm was discovered, he developed purpura hemorrhagica on the elbows, shoulders and back. This lasted only a few days and all evidence of it disappeared after treatment was instituted.

In none of the cases was there any anemia worthy of note. In all, the red count was practically normal and the hemoglobin tests (Dare) showed no case below 75 per cent. and only three below 85 per cent.

Of these seven cases showing infection with parasites, eosinophils were increased in only three cases and in only one of these was there a true eosinophilia. One case infected with the Trichiurus trichiura showed a 3 per cent. eosinophilia in a white count of 9,200 ; one case of Ascaris infection, a 2 per cent. eosinophile count in a total count of 20,000 whites, and the third case, the infection with the Trenia saginata, showed 8 per cent. eosinophils in a 10,000 total white count. It is easily seen then that in the first two, the Trichiurus trichiura infection with 276 easinophils and in the Ascaris infection with 400 eosinophils, there is no increase in the normal number of cells. In the last case, however, the Tania saginata infection, with 800 of these cells, there is the only absolute eosinophilia.

It will be seen then, that there was no constant set of symptoms present that could justly be referred to the helminthiasis. Further, the few symptoms that were evident bore no relation to any particular species of parasites. Case 6, the infection with the fat tape-worm, is the only case that could definitely be stated to have shown anything like a typical text-book picture. Here the poor appetite, some restlessness and irritability, slight loss of weight, mild anemia and the purpura hemorrhagica, with the actual eosinophilia, which disappeared with complete recovery following treatment with santonin and calomel, place this single case beyond question.

\section{SUMMARY}

1. Careful examination of the stools from 102 children from 2 to 12 years of age showed that $6.86^{\circ}$ per cent. were infected with intestinal parasites. In one case there was a double infection giving a total of eight infections. This low percentage is extremely interesting, especially when compared with those reported by the only two others who have carried on similar investigations. Schloss, of New York, from 280 examinations reports 28.57 per cent., and Stiles and Garrison from 123 examinations report 21.14 per cent.

2. Four (3.92 per cent.) of the cases were Trichiuris trichiura infection; two (1.96 per cent.) were Ascaris lumbricoides infections; one (.98 per cent.) was a Txnia saginata, and one (.98 per cent.) was a Trichimonas intestinalis. Comparing these with the relative frequency 
shown in other reports, we find the results very similar for these three species of parasites. In all reports, the Trichiuris trichiura is three to four times as prevalent as any other parasite. The Ascaris is usually mentioned as one of the most common intestinal worms, but the more recent reports seem to disprove this view; the report of Stiles and Garrison showing only .81 per cent. of cases harboring this worm.

3. Only a small percentage of cases infected with intestinal parasites display any obvious symptoms.

4. Eosinophilia was not constant as a symptom of helminthiasis, but when present, it accompanied the other clinical manifestations. Further, its presence bore no relation to the species of parasite harbored.

We realize that the small number of cases and the limits of this series of examinations must be remembered in considering the statistical value of our results. However, we feel that the results justify the conclusion that infection with intestinal parasites is much less frequent among the children of the poorer classes of Chicago than is generally conceded to be the case.

In conclusion, I wish to acknowledge my indebtedness to Dr. Julius H. Hess and to Dr. Solomon Strouse for assistance in the preparation of this report. Also to the members of the pediatric and pathologic staffs of the Michael Reese Hospital for many courtesies shown and to the Department of Pediatrics of Northwestern University Medical School through whom the work was made possible.

Michael Reese Hospital 